\title{
New trajectories of the Hungarian regional development: balanced and rush growth of territorial capital
}

\begin{abstract}
The basic assumption of the paper is that numerous similarities exist between the patterns of economic growth and territorial capital growth. The rush economic growth and rush growth of territorial capital are compared empirically at Hungarian micro-regional level from 2004 until 2010. After normalizing the dataset, a very novel spatial econometric method is applied, called a penalty for bottleneck. The results show that the constant rush growth of territorial capital is as harmful as economic recession. On the other hand, the decrease of infrastructural and social capital caused the rush growth of territorial capital in this period. Moreover, the key findings of two case studies suggest that the balanced growth of territorial capital will be created by the falling social inequalities and increasing infrastructural capital.
\end{abstract}

Keywords: territorial capital, rush growth, balanced development, endogenous assets.

\section{Introduction}

Year by year the territorial capital of certain Hungarian micro-regions were increasing significantly (Jóna-Hajnal 2014, Jóna 2015). On first sight, we might think that the rush growth of territorial capital (RGTC) may be desirable and benevolent but the rush growth prevents the harmonic and sustainable development in the long run. The constant RGTC is as harmful as economic recession.

János Kornai's rush growth theory has been adopted to analyse and to compare to the harmonic growth of territorial capital (HGTC) and RGTC. According to the basic assumption, empirical similarity exists between rush economic growth and RGTC; so many similarities can be founded between these mentioned two concepts.

The study focuses on the special changes of the Hungarian micro-regions' territorial capital. It is not concerned about demonstrating the theoretical background of territorial capital as a large number of scholars have already been carried this out; it rather demonstrates the results of empirical research. In this study the most important features of HGTC and RGTC are designed, moreover the paper answers the questions which Hungarian micro-regions emerged RGTC and what created it between 2004 and 2010. Finally, partial effects of the HGTC and RGTC are compared in the study.

a) University of Debrecen, Department of Social Science, H-4400, Nyíregyháza, Sóstói u. 2-4., Hungary. E-mail: jona.gyorgy@foh.unideb.hu 


\section{Theoretical background}

The concept of territorial capital enroots the paradigm of new regionalism, accepting the supply-oriented approach (Capello-Nijkamp 2009). It can gather and classify the endogenous and exogenous assets of territorial development and can be operationalized with special spatial econometric methods. The new paradigm needed to be introduced due to the early conjecture, that proved empirically, that endogenous and exogenous goods can significantly determine the regional economic growth (Aroca-Stimson-Stough 2014, Camagni-Capello 2014, Maillat-Kibir 2001, Stimson-Stough 2009).

In these days the politicians, decision-makers and territorial planners focus on issues of economic growth. The topic of speeding up this growth has become a public affair (sometimes almost a fetishism of growth can be found), thus, at the first sight, the notion of rush growth may be desirable and benevolent. Kornai, however, highlights that rush growth prevents the harmonic and sustainable development on the long run (KornaiDániel-Jónás-Martos 1971). Applying a radical but expressive simile: the man who grows $180 \mathrm{~cm}$ in 23 years is healthy but a man who grows $180 \mathrm{~cm}$ in 5 years (namely he increases extremely fast) is ill. Economic growth is similar to human development; it also has a special growth trajectory. It needs to move uniformly and predictably, to guarantee the sustainability of harmonic growth. If rush growth emerges over the long term, it can deform the developmental structure, finally leading to economic depression and crisis. In short term, the rush growth is acceptable and natural but in the long run it has harmful effects on the local economic system (Kornai-Simonovits 1977, Kourtit-Nijkamp-Stimson 2014).

Kornai identifies rush growth as a type of disequilibrium, meaning the regional growth rate accelerates, compared to its own and the countries growth rate (Kornai 1971). It can be explained in that the partial effects of the development factors are fluctuating consistently, excessively and disproportionately; the potential of a region is discordant. The other typical mark of rush growth (the opposite of the previous situation) is that the determinants of growth define, almost to the same extent, the development trajectory, and this static status exists over the long term. It rarely emerges in practice, it is only a theoretical opportunity and the first one can be found in the real economic process (Kornai 1972, Mihályi 2011).

The important feature of harmonic growth, as an opposite, is the rate of growth of certain regions at nearly the same rate as the nation's growth rate, occasionally, short-term outstanding increases can occur sometimes (Kornai 2006). Moreover, there are differences among the partial effects of development determinants but these are not significant and the standard deviation is also small. Later, the growth factors may shift to a greater or lesser extent; one time the first factor and then another factors overcomes but extreme changes cannot be revealed in the development structure; the growth potential of the region is harmonic. Simply put, balanced growth is a dynamic equilibrium state that is not static nor excessive. The rare and short-run spurts are not called rush growth only the permanent and static regional development can be defined as rush growth.

Hypothesis 1 is that rush economic growth is similar theoretically and empirically to RGTC.

According to hypothesis 2, significant differences can be revealed among the partial effects of the factors of HGTC and RGTC. 
The point of hypothesis 3 is that essential differences can be found in the rank of the partial effects of HGTC and RGTC at micro-regional level.

Hypothesis 4 alleges that RGTC is a barrier of sustainable economic growth; after the RGTC the decrease will be sharply higher than the result of rush growth.

Two aspects of the theoretical and methodological background of research are highlighted in the paper. Firstly, the trends of territorial capital growth differ in a certain country, some regions have a dynamic development trajectory, in other regions stagnation can be revealed, on the other hand, in some regions decrease can be measured. It explains that the study scrutinizes the RGTC at micro-regional level (LAU-1 or NUTS-4 region) between 2004 and 2010; in this period Hungary had 174 micro-regions. Secondly, regional economic growth and development are also directly and significantly determined by the endogenous and exogenous assets; both have to be analysed together, this is the main reason why the concept of territorial capital is applied. Kornai (1971) accepts and highlights these approaches too.

\section{Research model and applied methods}

Before beginning of operationalization, some important details need to be clarified. To date, RGTC has not been scrutinized, empirically, therefore in this study inductive methods were applied in some rare cases (Vieira-Tsotras 2013).

When researching territorial capital, seven types of capital can be identified; these arithmetic averages show the territorial capital ${ }^{1}$ (Capello 2007). The seven kinds of capital are the following: Economic, institutional, infrastructural, relational, human, social and cultural capital. Accepting the set theory, it may be more understandable, if the territorial capital of a micro-region is calculated as $\mathrm{tc}_{r, t}=\left\{\frac{\mathrm{HC}_{r, t}+\mathrm{InfC}_{r, t}+\mathrm{InSC}_{r, t}+\mathrm{SC}_{r, t}+\mathrm{CC}_{r, t}+\mathrm{EC}_{r, t}+\mathrm{RC}_{r, t}}{N_{\mathrm{kc}}}\right\}$ where tc is territorial capital, $\mathrm{HC}$ is human capital, InfC is infrastructural capital, InsC is institutional capital, $\mathrm{SC}$ is social capital, CC is cultural capital, EC is economic capital, RC is relational capital, $\mathrm{NKC}$ is the number of the kind of capital, $r$ is region and $t$ is time. The territorial capital of nation can be operationalized as logically $T C_{t}=\sum_{I=1}^{n}\left\{t c_{t}\right\}$ where TC is territorial capital at national level Perucca 2013).

In those micro-regions where the growth of territorial capital was harmonic, the territorial capital increased between half and double the average growth of territorial capital. So: $0,5 \overline{G_{t}} \leq H G_{t} \leq 2 \bar{G}$, where $\mathrm{HG}$ is a region where harmonic growth of territorial capital is measured, $\mathrm{G}$ is average growth of territorial capital.

The equation of RGTC is: $R G_{r, t} \geq 4\left(H G_{N, t}\right)$ where $\mathrm{RG}$ is a region where rush growth of territorial capital is measured, $N$ is national level namely the 174 micro-regions of Hungary.

In some years the average growth of territorial capital decreased, in this case, the RGTC is measured: $R G_{r, t} \geq\left|3\left(H G_{N, t}\right)\right|$.

The paper uses the set theory for plain language. Basically, the first set contains microregions in which the growth of territorial capital was harmonic, this set is called as HG. According to the previous definition, the second set embraces micro-regions in which the 
growth of territorial capital was rush, this set is named as RG. The numbers of both sets changed year on year. A certain micro-region does not belong to both sets; $\mathrm{HG}$ and RG were emerging as disjoint sets, so $H G \cap R G$.

Actually, the members of these sets were scrutinized separately and compared over a seven year term. The study only deals with RG and HG sets, the micro-regions where other territorial capital occurred, are excluded from the paper.

Every micro-region has territorial capital and these can be ranked based on their territorial capital. Moreover, within a framework of longitudinal research, the trend of territorial capital growth can be operationalized thus the rush and harmonic growth of territorial capital can be investigated.

The rush and balanced growth of territorial capital can be defined by flow variables, meaning chain relatives can demonstrate how territorial capital of micro-regions were shifting year by year and which micro-regions belong to HG or RG.

The items of research were mustered from the database of the Land Information System (Hungarian: TEIR). By applying Q-type principal component analysis (PCA), the multicollinearity was reduced and the number of variables can be eliminated (YuzGoodwin 2014). After the PCA, 48 variables remained in the model and these were classified within seven sub-indices, the average of seven sub-indices show the territorial capital of a micro-region. Ultimately, a matrix was created which consists of 58.464 (48 variables x 174 micro-regions x 7 years) cells (see Table 1).

Table 1

Variables and sub-indices constructing the territorial capital

\begin{tabular}{|c|c|c|}
\hline $\begin{array}{c}\text { Aggregated } \\
\text { index }\end{array}$ & $\begin{array}{l}\text { Sub-index/ } \\
\text { dimension }\end{array}$ & Variables \\
\hline \multirow{3}{*}{$\begin{array}{l}\text { Territorial } \\
\text { capital }\end{array}$} & $\begin{array}{l}\text { Economic } \\
\text { capital }\end{array}$ & $\begin{array}{l}\text { Total domestic income per capita } \\
\text { Net export sales revenue per } 1000 \text { people } \\
\text { Issued capital for } 1 \text { firm } \\
\text { Equity for } 1 \text { firm } \\
\text { Total firms for } 1000 \text { residents } \\
\text { High-tech business service per } 1000 \text { residents } \\
\text { Output per } 1 \text { firm } \\
\text { Entrepreneurship }\end{array}$ \\
\hline & $\begin{array}{l}\text { Infrastructural } \\
\text { capital }\end{array}$ & $\begin{array}{l}\text { Footpath and pavement per } 1 \mathrm{~km}^{2} \\
\text { Cycle path per } 1 \mathrm{~km}^{2} \\
\text { Length of the national road per } 1 \mathrm{~km}^{2} \\
\text { The length of the gas pipe per } 1 \mathrm{~km}^{2} \\
\text { Drinking water system for public utility per } 1 \mathrm{~km}^{2} \\
\text { The length of the sewer per } 1 \mathrm{~km}^{2} \\
\text { The size of the reservation per } 1 \mathrm{~km}^{2} \\
\text { The size of the total green area }\end{array}$ \\
\hline & $\begin{array}{l}\text { Institutional } \\
\text { capital }\end{array}$ & $\begin{array}{l}\text { The number of libraries per } 1000 \text { people } \\
\text { The number of the institutions for public culture per } 1000 \text { people } \\
\text { The number of museums per } 1000 \text { people } \\
\text { The number of theatres per } 1000 \text { people } \\
\text { The number of cinema seats per } 1000 \text { people } \\
\text { The number of post offices per } 1000 \text { people } \\
\text { The number of art communities per } 1000 \text { people }\end{array}$ \\
\hline
\end{tabular}




\begin{tabular}{|c|c|c|}
\hline $\begin{array}{c}\text { Aggregated } \\
\text { index }\end{array}$ & $\begin{array}{l}\text { Sub-index/ } \\
\text { dimension }\end{array}$ & Variables \\
\hline \multirow{4}{*}{$\begin{array}{l}\text { Territorial } \\
\text { capital }\end{array}$} & Human capital & $\begin{array}{l}\text { The number of infant mortality per } 1000 \text { live-birth } \\
\text { The number of General Practitioners per } 1000 \text { people } \\
\text { The number of chemist's per } 1000 \text { people } \\
\text { The number of people enrolled in libraries per } 1000 \text { people } \\
\text { The number of students taking part in tertiary education per } 1000 \text { people } \\
\text { The number of teachers working in tertiary education per } 1000 \text { people }\end{array}$ \\
\hline & Social capital & $\begin{array}{l}\text { The number of the registered unemployed per } 1000 \text { people in active age } \\
\text { The daily average number of people in the communal kitchen } \\
\text { The number of people paying taxes per } 1000 \text { people } \\
\text { The number of crimes with prosecution per } 1000 \text { people } \\
\text { The number of economic crimes per } 1 \text { company } \\
\text { Domestic migration difference } \\
\text { Hoover-index }\end{array}$ \\
\hline & $\begin{array}{l}\text { Relational } \\
\text { capital }\end{array}$ & $\begin{array}{l}\text { The number of Internet users per } 1000 \text { people } \\
\text { The number of mobile phone subscriptions per } 1000 \text { people } \\
\text { The number of non-profit organizations per } 1000 \text { people } \\
\text { The number of clubs for old people and the number of the members } \\
\text { in them per } 1000 \text { old people }\end{array}$ \\
\hline & $\begin{array}{l}\text { Cultural } \\
\text { capital }\end{array}$ & $\begin{array}{l}\text { The number of the members of the art communities per } 1000 \text { people } \\
\text { The number of theatre-goers per } 1000 \text { people } \\
\text { The numbers of the participants on a cultural event per } 1000 \text { people } \\
\text { The number of the museum visitors per } 1000 \text { people } \\
\text { The number of the people going to permanent theatres per } 1000 \text { people } \\
\text { The number of cinema visits per } 1000 \text { residents } \\
\text { The number of monuments per } 1000 \text { people }\end{array}$ \\
\hline
\end{tabular}

Source: own calculation.

After normalization and weighting, the figures were corrected with a very novel way that is referred to as Penalty for Bottleneck (Ács-Szerb 2012). Finally, the micro-regions with harmonic and rush growth were selected according to the above definitions. This calculation was carried out for each year.

As already indicated, this model includes seven explanatory variables. The economic capital shows the economic performance of the region; Camagni calls these rivalry and tangible goods. Many scholars used similar indices measuring the economic capital (Capello et al. 2009, Brasili 2010, Veneri 2011, Brasili et al. 2012). Furthermore, the infrastructural capital contains the aptness and size of the elements of the infrastructure; the same indicators were used in studies by Capello et al. 2009, Brasili 2010, Russo et al. 2010, Brasili et al. 2012, Russo-Servillo 2012.

The institutional capital represents a micro-region's public institutions and their services. It is typical that the cultural institutions appear (one exception is the post office), between the institutional and the cultural capital emerge a close theoretical and empirical correlation in this model. Caragliu and Nijkamp (2008) also applied a similar indicator system to these variables. Human capital expresses two aspects of local society: on the one hand, the health condition of the population, and, on the other hand, the region's knowledge level. The health status also determines the regional welfare; if the population is healthy, the economic output and performance may increase, in parallel the social transfers decrease. The health condition is operationalized with the traditionally accepted indicators 
(e.g. infant mortality, life expectancy and so on), the knowledge degree is measured by the number of students and teachers participating in tertiary education and the number of people enrolled in the libraries (Kunzmann 2007, Caragliu-Nijkamp 2008, Camagni et.al. 2011, Brasili et.al. 2012, Russo-Servillo 2012).

The social capital refers to the level of social integration (Bourdieu 1983). It has two dimensions: (1) employment and (2) local social inequalities (Putman 2000). The first one is measured - among the others - with the employment rate of the sub-regions and the second one embraces the Hoover-index and so on; both effectively demonstrate the level of social integration. Additionally, homelessness causes social disintegration (it does not mean that the homeless people are harmful to society but the phenomenon itself can lead to disintegration in the local society). It is notable that the institution system for the homeless functions in bigger cities and metropolises (of course there are some exceptions), but the public kitchens (kitchens for the poor) are concerned about the groups living in social exclusion in small villages or towns. In general, the local trust relations can be measured through the observation of economic crime (Camagni-Capello 2015, Russo et al. 2010, Veneri 2011, Brasili et al. 2012).

The relational capital firstly includes the communication devices. The relational nets can come into being formally and informally. The first one usually occurs in civilian organizations, the latter evolves in formal and informal clubs (club-goods). In Hungary both are relatively new. In the third sector the relational capital can be accumulated, which can be converted to the economic capital and becomes the driving force of regional growth. The clubs for the old (here special club-goods are formed) belong to the relational capital on account of the local welfare is determined too by the quality of interactions of old people (Camagni et al. 2011). Moreover, the cultural capital embraces the number of the different cultural institutions and their capacity (Caragliu-Nijkamp 2008, Brasili et al. 2012). The more details can seen in Table 2.

Table 2

Main data of principal component analysis

\begin{tabular}{c|c|c|c|c|c|c}
\hline Year & $\begin{array}{c}\text { Number of } \\
\text { principal } \\
\text { components }\end{array}$ & $\begin{array}{c}\text { Measure of } \\
\text { Sampling } \\
\text { Adequacy } \\
\text { (MSA-test) }\end{array}$ & $\begin{array}{c}\text { Kaiser-Meyer- } \\
\text { Olkin (KMO- } \\
\text { test) }\end{array}$ & $\begin{array}{c}\text { Durbin- } \\
\text { Watson-test }\end{array}$ & $\begin{array}{c}\text { Total variance } \\
\text { explained, \% }\end{array}$ & Redundancy \\
\hline 2004 & 7 & 0.68 & 0.711 & 1.985 & 71.45 & 0.514 \\
2005 & 7 & 0.71 & 0.763 & 2.249 & 82.58 & 0.532 \\
2006 & 7 & 0.67 & 0.757 & 2.198 & 78.42 & 0.494 \\
2007 & 7 & 0.78 & 0.801 & 1.995 & 84.62 & 0.501 \\
2008 & 7 & 0.79 & 0.812 & 2.366 & 78.29 & 0.551 \\
2009 & 7 & 0.77 & 0.809 & 2.341 & 79.32 & 0.519 \\
2010 & 7 & 0.81 & 0.825 & 2.113 & 80.35 & 0.533
\end{tabular}

$\mathrm{N}=174$; sig.: $\mathrm{p}<0,05$.

a) $\operatorname{Red}=\sqrt{\frac{\sum_{i=1}^{m} \sum_{\substack{j=1 \\ j \neq i}}^{m} r_{i, j}^{2}}{m(m-1)}}$.

Source: own calculation. 


\section{Results}

Calculating the arithmetic average (average) between 2004 and 2010 the territorial capital as the national level was increasing by $9,66 \%$, indicating that the annual average growth of territorial capital was $1,38 \%$. Between 2005 and 2006, the highest accumulation of territorial capital emerged and then the trend slowed owing to the credit crisis of 2008, after that the trend of territorial capital was corrected (see Figure 1).

The change of the territorial capital at a national level between 2004 and 2010

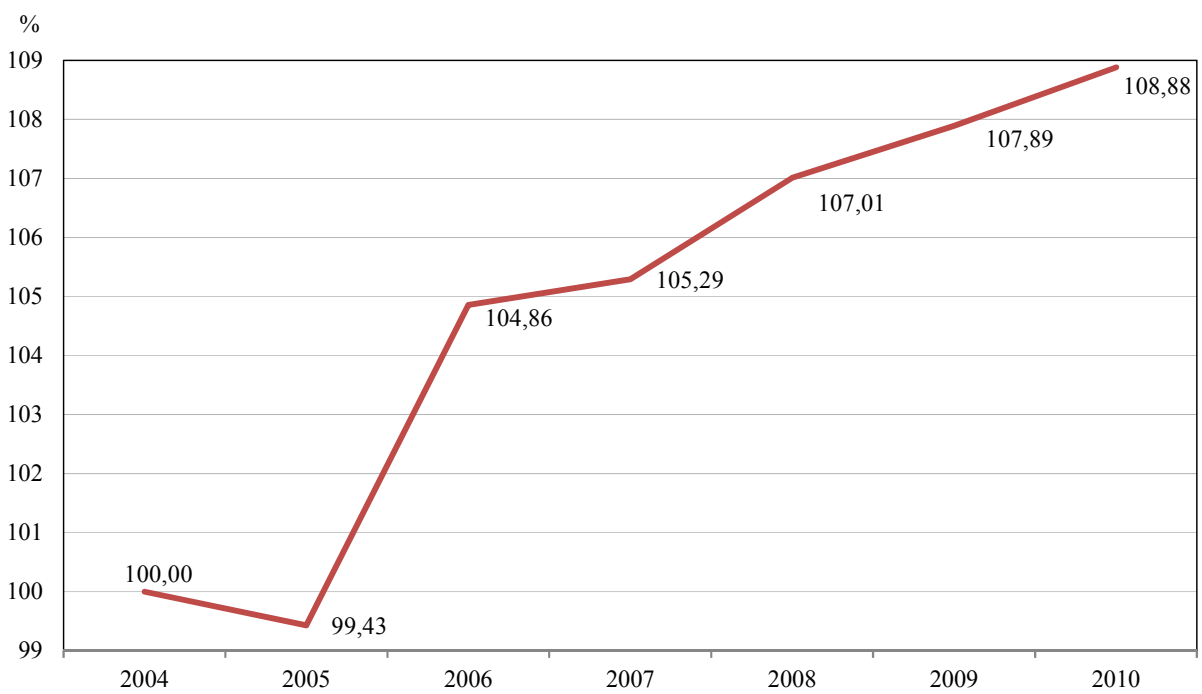

Moreover, the paper answers the question as to the extent of standard deviation among the partial effects of territorial capital. According to Kornai, the rush growth is determined significantly as well by the high standard deviation of partial effects. Accepting this qualitative thesis, the high standard deviation of the partial effects of territorial capital (one has high partial effect, and another has low partial effect specifically the standard deviation is high among them) causes RGTC. Basically, Hypothesis 2 will be tested empirically; it is confirmed statistically by the Figure 2 .

In general, the Figure 2 compares the standard deviation of the partial effects of $\mathrm{HG}$ and RG. It is self-evident that the standard deviation of RG is higher than HG, strengthening that rush economic growth is similar to RGTC so Hypothesis 2 can be accepted. The standard deviation of RG was fluctuating hectically in the first period; from 2007 it was decreasing but did not level off to the standard deviation of HG. The standard deviation of the partial effects of RG started increasing again due to the effect of the debt crisis of 2008. The HG factors were determined as well by the financial depression but its standard deviation increased slightly. 
The change of the deviation between the capital types determining the HG and RG

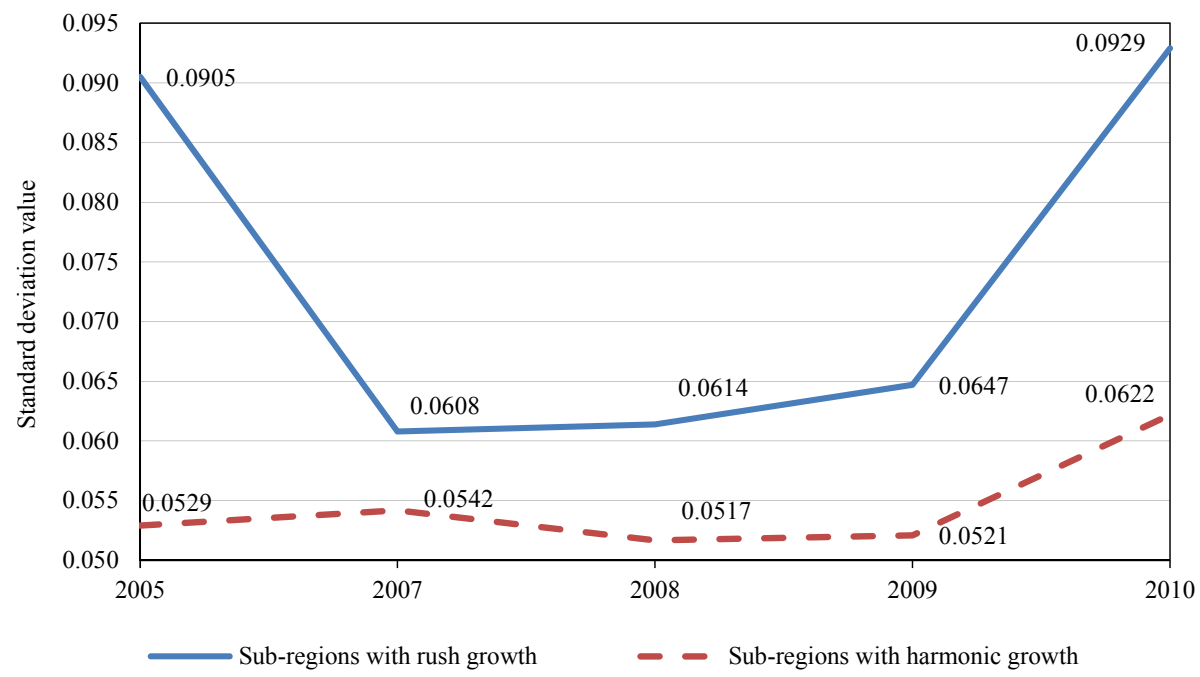

The paper then scrutinises what types of capital define RG and HG sets; it is calculated by multiple linear regression analysis. Simply put, it can be inspected what types of capitals determine the shift of territorial capital.

First, multiple correlation analysis is applied to reveal the statistical connection among the variables of RG and HG. In this dynamic model the connection of the strength and direction of the explanatory and dependent variables were calculated as a set. So: $\Delta H G_{r, t}=$ $H G\left\{\beta_{0}+\beta_{1} X_{1}+\beta_{2} X_{2}+\beta_{7} X_{7}+\varepsilon\right\}$, and $\Delta R G_{r, t}=R G\left\{\beta_{0}+\beta_{1} X_{1}+\beta_{2} X_{2}+\beta_{7} X_{7}+\varepsilon\right\}$. Finally, the results of regression can explain difference among the factors of RG and HG.

The partial effect of independent variables can be measured by standardized regression coefficient; it is the so-called beta value. The beta value demonstrates the effect of explanatory power of independent variable on depend variable. It can only be taken into account, if the significance level of t-probe is suitable $(p<0,05)$.

The RGTC can be operationalised in 20 micro-regions from 2004 to 2005 . Figure 3 shows that among the territorial capital structures of RG and HG, significant differences can be revealed; for example the partial effect of economic capital was the highest and the partial effect of cultural capital was the lowest in RG. Moreover, within the ranking of the partial effect of types of capital a large number of differences can be found between two sets: the territorial capital growth of HG was defined by the relational-, economic- and institutional capital. 
The capital types determining the territorial capital of the sub-regions with rush and harmonic growth in 2005 (beta-value)

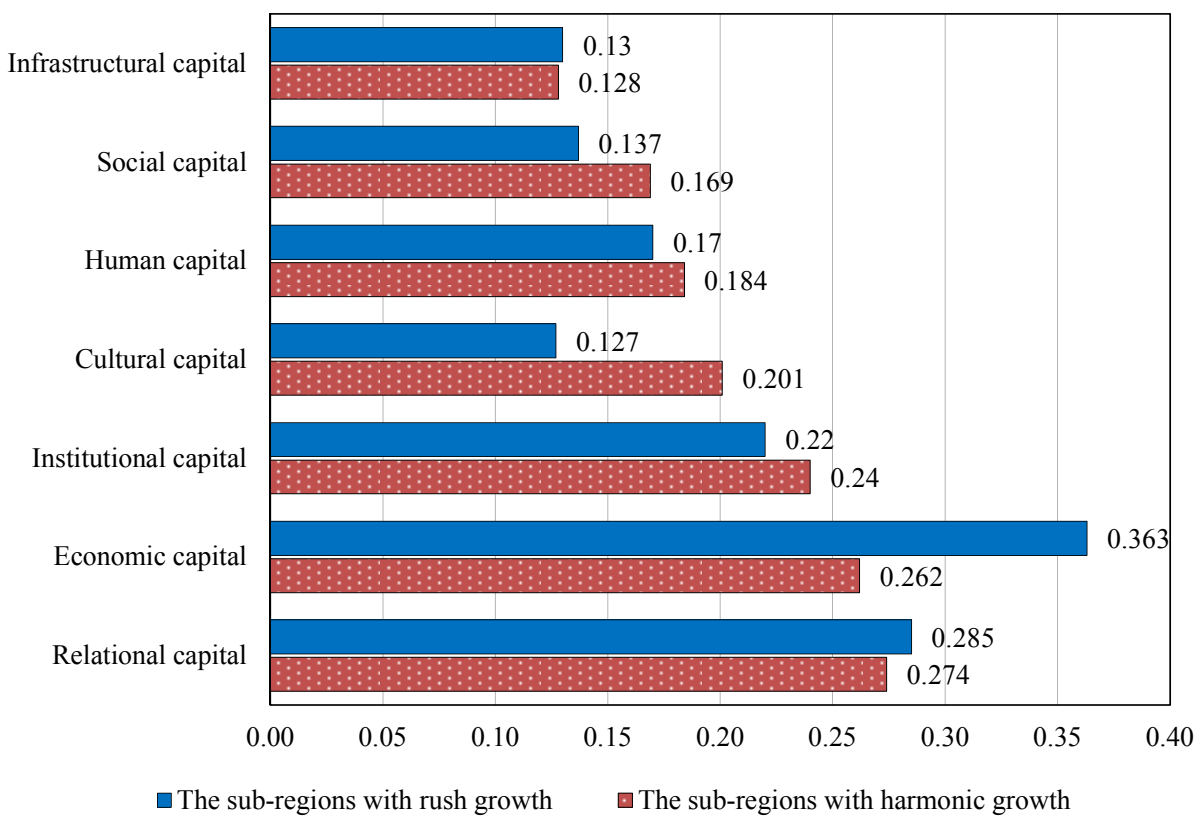

Nevertheless, the partial effects of three types of capital were the highest in the RG as well, but the ranking of types of capital is confused: the economic capital is the strongest than relational- and institutional capital. Interestingly, in RG the partial effect of social capital was significantly lower than in HG. The growth of RG was determined by the exogenous assets, the HG was defined in particular by endogenous goods. More broadly, the endogenous development could cause HGTC, the hegemony of exogenous goods could impose RGTC.

In 2006, the growth of territorial capital peaked; the territorial capital growth was 6.05 percentage points. Compared to the average annual growth of territorial capital, it is relatively high but not extreme. In such growth conditions, if the RGTC had been defined by the average growth of territorial capital of one and a half, only one micro-region (IbrányNagyhalászi micro-region) would have belonged to the RG. In this year RG became empty, $\mathrm{RG}=\varnothing$. Put another way, the 6.05 percentage point growth of territorial capital can create a stable equilibrium of territorial capital growth at national and micro-regional level. This growth trend may impede the RGTC.

32 micro-regions belonged to RG in 2007. The HG was determined consistently by relational-, economic- and institutional capital (see Figure 4). In contrast, the HG was defined by relational-, economic- and infrastructural capital; the partial effect of last one is significant. In a nutshell, in RG, the partial effects of social- and infrastructural capital were stronger, and the partial effect of institutional capital was weaker than in HG. These three differences caused RGTC in 2007. 
The capital types determining the territorial capital of the sub-regions with rush and harmonic growth in 2007 (beta-value)

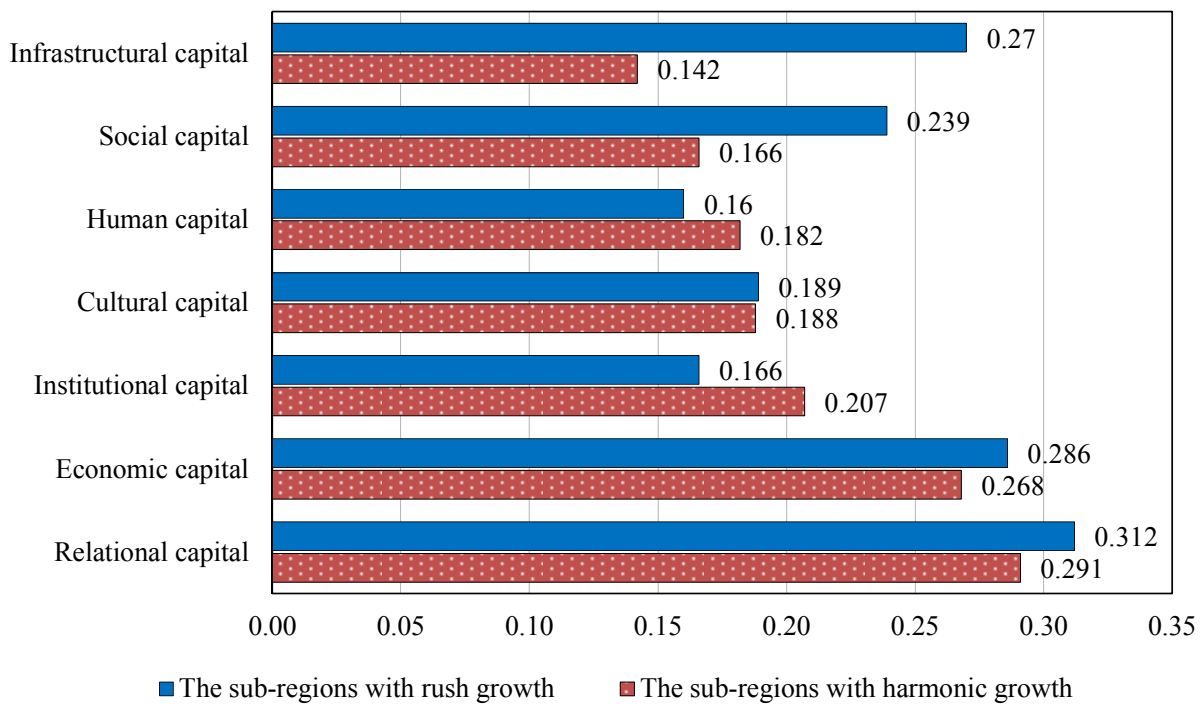

In $2008 \mathrm{RG}$ had 39 objects and their territorial capital structure changed basically compared to previous years: the partial effect of types of capital decreased in RG (see Figure 5). The partial effect of infrastructural-, relational- and social capital decreased significantly, and this circumstance caused RGTC in 2008.

The capital types determining the territorial capital of the sub-regions with rush and harmonic growth in 2008 (beta-value)

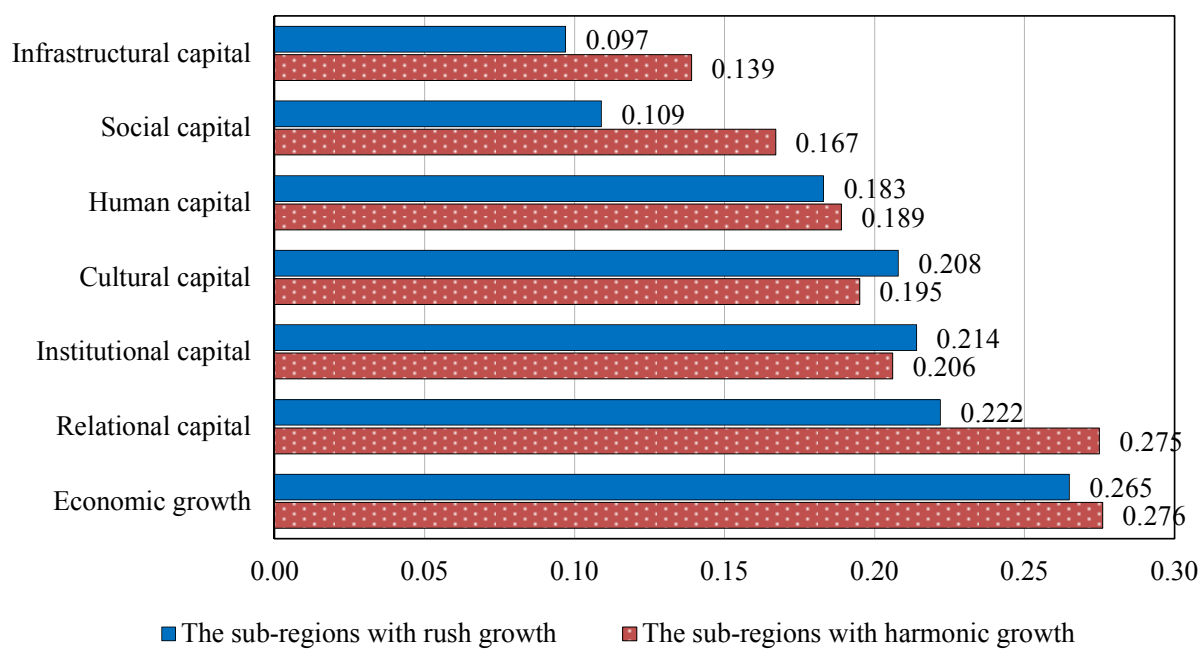


In 2009, the following year, 53 micro-regions could be found in RG. The effect of the economic crisis on territorial capital structure and the following trend was directly very harmful. Compared to previously, the growth factors of RG and HG also reshaped. Most evidently, the partial effect of economic and cultural capital increased in RG micro-regions; in parallel, the partial effect of relational capital decreased considerably (see Figure 6). The spatial equilibrium overturned because of the shifted situation.

Figure 6
The types determining the territorial capital of the sub-regions with harmonic and rush growth in 2009
(beta-value)

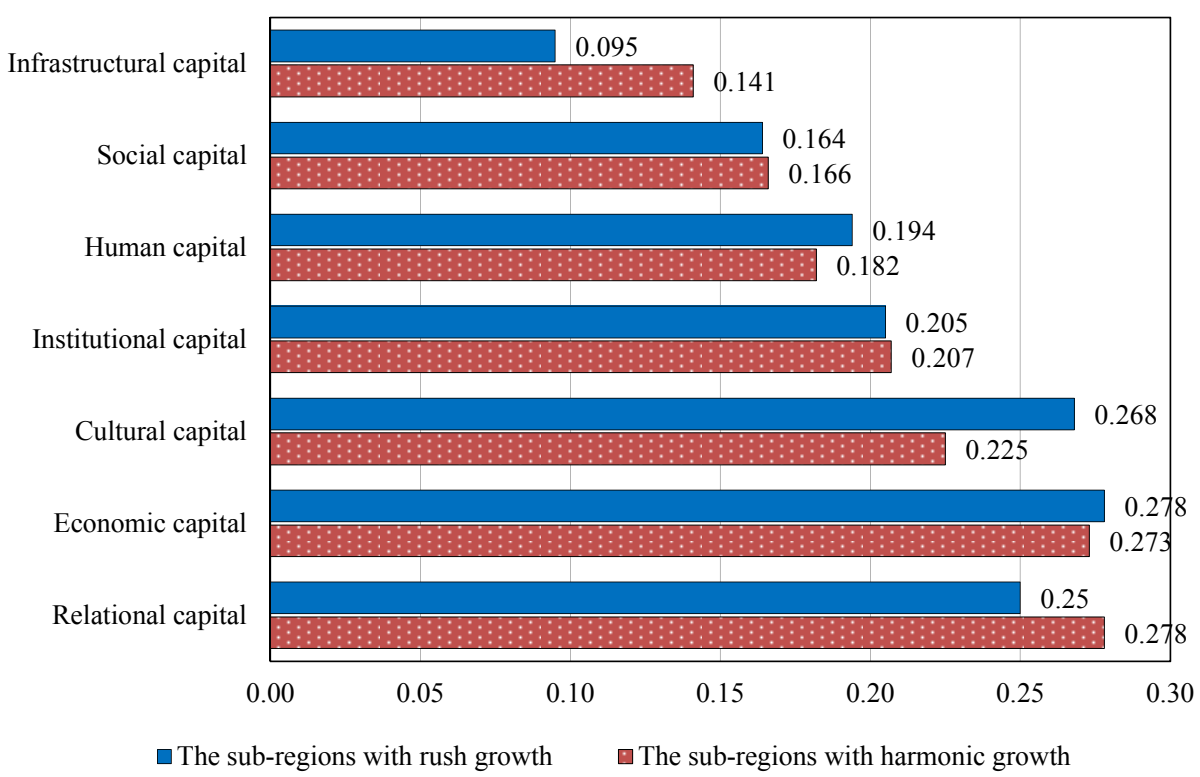

In RG, there were 52 objects in 2010 , see the Figure 7. It is important that only two differences can be found between RG and HG: the partial effects of infrastructural and social capital are lower in RG than in HG. The territorial capital structure of RG was almost similar to HR except for the above mentioned two capitals. In this year, on the one hand, RGTC was founded owing to both partial effects of kind of capitals decreased, and the other, the standard deviation shot up significantly among the types of capital. More precisely, after the economic crisis, RGTC was formed by the sudden rise of social inequalities and the gradual fall of the partial effect of infrastructural capital.

Finally, in RG the effect of the kind of capital emerged disproportionately compared to HG. In the territorial capital structure, the hegemony of exogenous assets can hamper the steady and harmonic development, meaning the endogenous goods have to be exploited more to reach a balanced growth of territorial capital. Those micro-regions were able to stand on HGTC that could utilize endogenous process, mostly their relational capital and complex economic networks. In every year, the territorial capital structure of RG was changing but in general, the partial effects of infrastructural and social capital were falling sharply. Overall, the infrastructural conditions were decreasing (other sectors were 
developed instead of infrastructure) in this period, in contrast, the local social inequalities were rising and this complex status caused RGTC.

The capital types the territorial capital of the sub-regions with harmonic and rush growth in 2010 (beta-value)

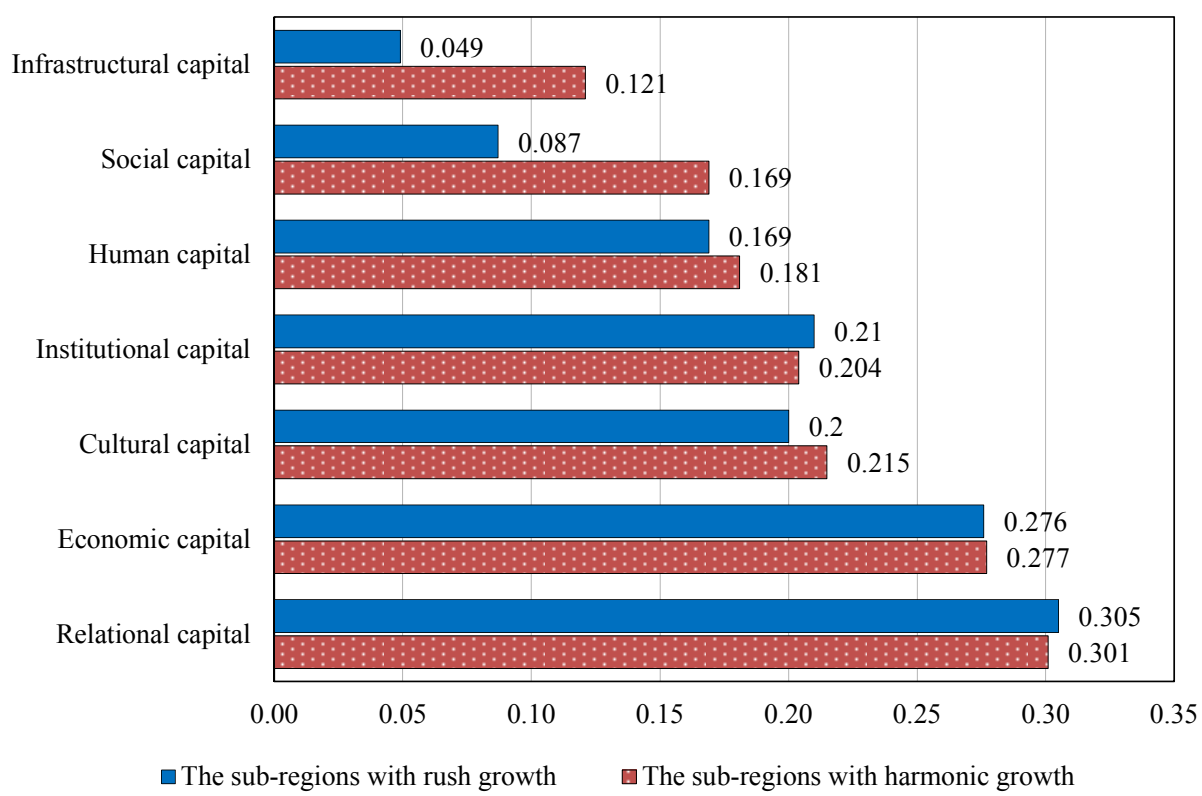

Basically, these figures show that Hypothesis 3 can be accepted as well.

Table 3 presents how many times RGTC formed in certain micro-regions. The number of objects of RG doubled almost because of the debt crisis of 2008; it then decreased slightly.

Table 3

The change of the number of objects RG and HG between 2005 and 2010

\begin{tabular}{c|r|r|r|r|r|r}
\hline Denomination & 2005 & 2006 & 2007 & 2008 & 2009 & 2010 \\
\hline The number of objects of RG & 20 & 0 & 32 & 39 & 53 & 52 \\
The number of objects of HG & 84 & 102 & 71 & 69 & 64 & 61
\end{tabular}

Source: own calculation.

The RGTC has no geographical patterns in Hungary. However, the results suggest that the RGTC created regularly in the micro-regions with low competitiveness but it rarely occurred in developed micro-regions as well (see Figure 8). 


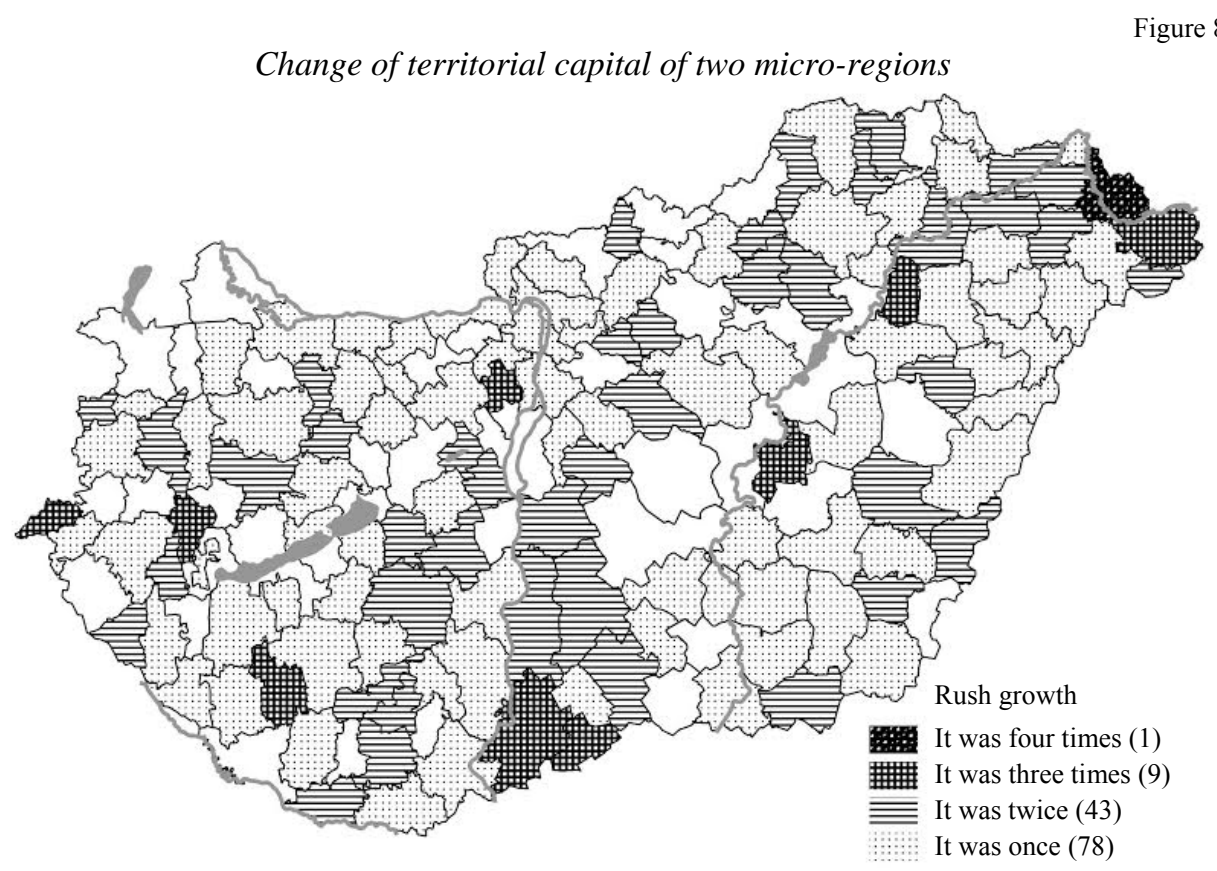

\section{A short case study regarding two micro-regions}

In this section, two case studies are outlined to illustrate empirically the characters, patterns and consequences of RGTC in practice. It is important to recognize empirically the effects of RGTC on regional economic development and the accumulation of territorial capital at local level. It may also provide a good example and systematic evidence for other regions where RGTC has a negative effect on the balanced regional growth and development.

First, the territorial capital trends of Vásárosnamény and Ibrány-Nagyhalász have to be scrutinized; the results are shown in Figure 8. RGTC appeared in Vásárosnamény four times and only once in Ibrány-Nagyhalász. In Vásárosnamény the RGTC was growing rapidly for four years, following which, the trajectory of territorial capital fell dramatically. It simply means that the RGTC prevents harmonic and equilibrium growth, Kornai's qualitative theses and Hypothesis 4 of the paper can be fortified empirically too. Moreover, between the regional economic development and territorial capital growth so many similarities can be found.

The development of the Ibrány-Nagyhalász micro-region was similar to Vásárosnamény. The difference that emerged between them is that in 2006 the RGTC lasted only one year in Ibrány-Nagyhalász and after that its territorial capital was decreasing sharply. 
Change of territorial capital of two micro-regions

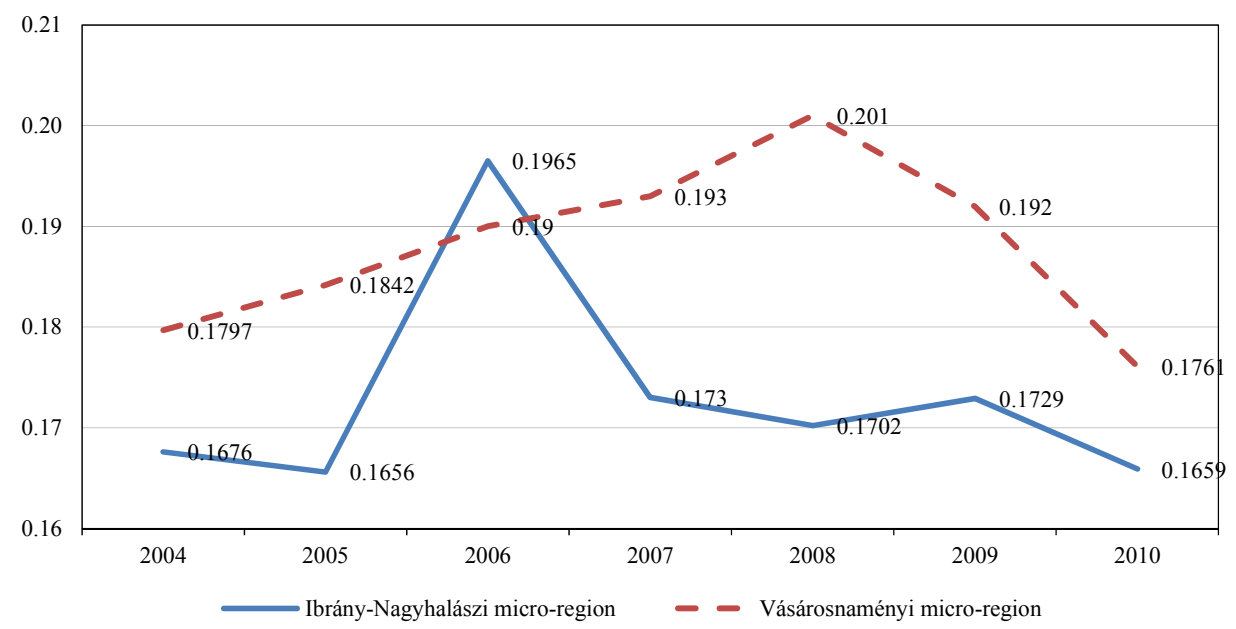

Finally, if the average growth of territorial capital had been higher, the number of objects of RG would have been lower. Empirical evidence demonstrates that the growth of annual 6 percent point of territorial capital was able to reduce the number of RG, see 2006 . Moreover, the economic crisis of 2008 owing to the number of RG shot up significantly, meaning that the territorial capital structure of the most micro-regions was deformed. Furthermore, between the partial effects and the rank of kind of capitals of RG and HG emerged substantially. To conclude, the partial effects of social- and infrastructural capital decreased mostly caused the RGTC; the RGTC was determined by exogenous assets, as opposed to the HGTC, which was determined by endogenous goods.

\section{Conclusions}

Kornai's theses have actual messages for regional development policy. Those territorial assets should be mobilized which guarantee slow but sustainable economic development. Contrary to this, mainly in Hungary, those territorial goods have been exploited which impose RGTC. It is because the growth-oriented world needs rapid, significant and spectacular economic development that it contributes to the rapid but unstable growth of territorial capital.

The HGTC causes strong regional economic development trajectory on the long run; notwithstanding, RGTC was preferred by regional decision makers, territorial experts, planners and stakeholders owing to bringing political capital and legitimacy. It is because the local society believes that rush growth is a benevolent phenomenon thus it has been established by political leaders and territorial experts. If rush growth is conducted in practice by stakeholders or/and territorial planners, the local society legitimatise the leaders acts. Fundamentally, this is the dilemma: the RGTC brings political legitimacy in the short run but can upset local regional development; on the contrary, the HGTC may achieve lower political legitimacy but can contribute sustainable growth in the long run. The 
empirical study recommends that for local leadership HGTC is preferable to RGTC. Moreover, it is relevant to understand that harmonic growth does not mean regional efficiency reduction.

To conclude, the HGTC will be created by falling social inequalities and increasing infrastructural background. The partial effects of RGTC ought to be harmonized to the partial effects of HGTC thus the micro-regions with RGTC will be able to maintain harmonic growth trajectory.

\section{Acknowledgement}

The research was financed by Pallas Athéne Geoploitical Foundation.

\section{REFERENCES}

Ács, J. Z.-Szerb, L. (2012): Global entrepreneurship and development index 2012 Edward Elgar, Cheltenham. Aroca, P.-Stimson, R.-Stough, R. (2014): Using a structural equation model to analyze potential determinants to spatial variations in endogenous regional growth performance In.: Kourtit, K.-Nijkamp, P.Stimson, R. (eds.): Applied regional growth and innovation models pp. 335-360., Springer, BerlinHeidelberg.

Bourdieu, P. (1983): The Forms of Capital In: Richardson, J. G.: Handbook of Theory and Research for Sociology of Education pp. 241-258., Greenwood, New York.

Brasili, C.-Saguatti, A.-Benni, F. (et.al.) (2012): The impact of the economic crisis on the territorial capital Italian regions http://www-sre.wu.ac.at/ersa/ersaconfs/ersa12/e120821aFinal00646.pdf (downloaded: 1. 08. 2015)

Brasili, C. (2010): Local and urban development in the European Union http://wwwsre.wu.ac.at/ersa/ersaconfs/ersa11/e110830aFinal01382.pdf (downloaded: 1. 08. 2015)

Camagni, R.-Capello, R. (2015): Agglomeration economies and urban location benefits In.: Michelangeli, A. (ed.): Quality of life in cities pp. 143-162., Routledge, New York.

Camagni, R. (2011). Creativity, culture and urban milieux In.: Girard, L. F. (ed.): Sustainable city and creativity pp.183-199., Ashgate, Burlington.

Camagni, R.-Capello, R. (2015): Second-rank cities dynamics: theoretical interpretations behind their growth potentials European Planning Studies 23 (6): 1041-1053.

Capello, R.-Nijkamp, P. (eds.) (2009): Regional growth and development theories in the XXI. century Edwar Elgar, Cheltenham.

Capello, R. (2007): A forecasting territorial model of regional growth: the MASST model The Annals of Regional Science 41 (4): 753-787.

Coleman, J. S. (1988): Social capital in the creation of human capital American Journal of Sociology 94: S95S120.

Jóna, Gy.-Hajnal, B. (2014): A magyarországi kistérségek területi tőkéjének alakulása Területi Statisztika 54 (2): $99-118$.

Jóna, Gy. (2015): Determinants of Hungarian sub-regions' territorial capital European Spatial Research and Policy 22 (1): 101-119.

Kornai, J. (1971): Anti-equilibrium North-Holland Publishing Company, Amsterdam.

Kornai, J.-Dániel, Zs.-Jónás, A.-Martos, B. (1971): Plan-sounding Economics of Planning 11 (1-2): 31-58.

Kornai, J.-Simonovits, A. (1977): Decentralized control problems in Neumann-economies Journal of Economic Theory 14 (1): 44-67.

Kornai, J. (1972): Rush versus harmonic growth North-Holland Publishing Company, Amsterdam-London.

Kornai, J. (2006): By Force of Thought. Irregular Memoirs of an Intellectual Journey MIT Press, LondonCambridge.

Kourtit, K.-Nijkamp, P.-Stimson, R. (eds.) (2014): Applied regional growth and innovation models Springer, New York-London. 
Kunzmann, K. R. (2007): Medium-sized cities and creative industries. Cultural Identity, Cultural Mapping and Planning in the Oresund Region http://www.kulturplan-oresund.dk/pdf/ aktivitetsplan/071017 Potsdam_Creativity2.pdf (downloaded: 1.08. 2015)

Maillat, D.-Kibir, L. (2001): The learning region and territorial production systems In.: Johansson, B.-Karlsson, C.-Stough, R. R. (eds.): Theories of endogenous regional growth pp. 255-277., Springer, Heidelberg.

Mihályi, P. (2011): A gazdasági növekedés gyorsításának esélyei Magyarországon 2030-ig Competitio 10 (2): $5-27$.

Perucca, G. (2013): The role of territorial capital in local economic growth: evidence from Italy European Planning Studies 21 (4): 502-521.

Putman, R. D. (2000): Bowling alone Simon and Schuster, New York.

Russo, A. P.-Servillo, L. (2012): The attractiveness of regions and cities for residents and visitors www.espon.eu/export/sites/.../31_A_Russo.ppt (downloaded: 1. 10. 2012)

Stimson, R. J.-Stough, R. R. (2009): Leadership, institutions and regional endogenous development Edward Elgar, Cheltenham.

Tranos, E.-Nijkamp, P. (2013): A távolság halálának új vizsgálata Tér és Társadalom 27 (3): 3-27.

Veneri, P. (2011). Territorial identity in Italian NUTS-3 regions Universitá Politecnica delle Marche, Ancona. http://www.grupposervizioambiente.it/aisre/pendrive2011/pendrive/Paper/paper vert AN june 2 011.pdf (downloaded: 01. 08. 2015)

Vieira, M. R.-Tsotras, V. J. (2013): Spatio-temporal databses complex motion pattern queries Springer, New York-London.

Yuz, J. I.-Goodwin, G. C. (2014): Sampled-data models for linear and nonlinear systems Springer, LondonHeidelberg. 